UDK: 339.727.22:578.834

Originalan naučni rad

Biblid: 1451-3188, 20 (2021)

Primljen 16.2.2021.

God XX, br. 75, str. 5-19

DOI: https://doi.org/10.18485/iipe_ez.2021.20.75.1

Odobren 10.5.2021.

\title{
PRIMENA PRAVNOG OKVIRA EVROPSKE UNIJE ZA PROVERU STRANIH DIREKTNIH INVESTICIJA U VREME PANDEMIJE COVID-19
}

\begin{abstract}
Duško DIMITRIJEVIĆ*
Apstrakt: Zajednička trgovinska politika Evropske unije posvećuje posebnu pažnju stranim direktnim investicijama. Ovo stoga, što su strane direktne investicije važan izvor ekonomskog rasta, zapošljavanja i inovacija, i što predstavljaju ključni faktor socijalnog i ekonomskog razvoja država članica. U periodu pre izbijanja pandemije virusa Covid-19 Evropska unija je predstavljala glavnog investitora i najznačajniju destinaciju za strane investicije u svetu. Širenjem virusa došlo je do poremećaja u globalnim lancima snabdevanja, do destabilizacije finansijskih tržišta, a potom i do negativnih efekata stranih investicija nastalih preuzimanjem imovine i tehnolologija u strateški važnim sektorima evropske privrede. Da bi izbegla recesijski udar, Evropska unija je odlučno reagovala u cilju zaštite sopstvenih ekonomskih interesa. Tako je, već u martu 2019. godine, usvojila Uredbu 2019/454 kojom je uspostavila okvir za proveru stranih direktnih investicija iz trećih zemalja. Operativno sprovođenje ovog pravnog okvira započeto je 11. oktobra 2020. godine. Države članice Evropske unije ovlašćene su da pozivom na razloge bezbednosti i zaštite javnog poretka vrše proveru stranih direktnih investicija posredstvom postojećih i novouspostavljenih mehanizama kontrole. Mehanizmi kontrole pretpostavljaju usaglašenost domaćeg zakonodavstva sa ustanovljenim pravnim okvirom čije efektuiranje u praksi ne bi trebalo da dovede do drastičnijih odstupanja od uobičajenih standarda međunarodnog investicionog i trgovinskog poslovanja.
\end{abstract}

Ključne reči: Evropska unija, strane direktne investicije, mehanizmi kontrole, bezbednost, javni poredak.

\footnotetext{
* Institut za međunarodnu politiku i privredu, Beograd.

E-mail: dimitrijevicd@diplomacy.bg.ac.rs.

Rad je nastao u okviru naučnoistraživačkog projekta: „Srbija i izazovi u međunarodnim odnosima 2021. godine“, koji finansira Ministarstvo prosvete, nauke i tehnološkog razvoja Republike Srbije, a realizuje Institut za međunarodnu politiku i privredu tokom 2021. godine.
} 


\section{1) UVOD}

Kretanje kapitala u svetu nezamislivo je bez stranih direktnih investicija. Uz međunarodnu trgovinu, strane investicije su jedan od ključnih faktora globalizacije svetske privrede i regionalnog povezivanja. Evidentan primer predstavlja upravo Evropska unija gde je globalizacija uticala na integraciju privreda država članica i na povezivanje evropske privrede sa privredama trećih zemalja. Pomenuti procesi išli su uporedo sa integracijom evropskog tržišta u globalno tržište. Sve to je imalo višestruki značaj za ekonomski rast država članica i prosperitet Evropske unije, budući da su integrativnim procesima liberalizovani tokovi stranog kapitala i da su kreirana područja slobodne trgovine. Nakon ekonomske recesije, u prvoj deceniji XXI veka, pokazalo se da ovakav koncept privrednog razvoja može doneti i određene negativne efekte, koji se ispoljavaju kroz rast deficita u trgovinskim odnosima sa inostranstvom ili kroz nelojalno preuzimanje preduzeća u ključnim granama evropske privrede. Situacija je dodatno pogoršana eksponencijalnim širenjem pandemije virusa Covid-19. Aktulena zdravstvena kriza povećala je rizik za ključnu industrijsku infrastrukturu i lanac snabdevanja kritičnim resursima. Otvorenost evropskog tržišta prema stranim direktnim investicijama time je dovedena u ozbiljnu opasnost. U vanrednim okolnostima, pomenute tendencije mogu uticati znatno na javni poredak i bezbednost država članica. U cilju preventivnog delovanja Evropska unija je preduzela niz mera trgovinske politike kojima štititi svoje strateške kapacitete. Usvajanjem nove pravne regulative o kontroli stranih direktnih investicija Evropska unija nastojala je da se prilagodi zahtevima vremena i potrebama zaštite evropske privrede. Delotvornost usvojenih mera i pravnih okvira na društveno-ekonomskom planu zavisiće, međutim, i pre svega, od iskazane solidarnosti i koordiniranog pristupa u celoj Uniji. ${ }^{1}$

\section{2) REGULISANJE NADLEŽNOSTI U OBLASTI INVESTICIJA U EVROPSKOJ UNIJI}

Do stupanja na snagu Lisabonskog ugovora, 1. decembra 2009. godine, investicioni ugovori država članica, uz ugovore o slobodnoj trgovini, predstavljali su glavne izvore međunarodnog investicionog prava u odnosima između Evropske unije i trećih zemalja. ${ }^{2}$ Nakon toga, na osnovu Ugovora o funkcionisanju Evropske

\footnotetext{
${ }^{1}$ Navedeni pristup najbolje se očituje kroz usvajanje Investicijske inicijative kojom je Komisija odobrila usmeravanje znatnih finansijskih sredstava kohezijske politike (37 milijardi evra), strukturnih fondova (28 milijardi evra), Fonda solidarnosti (800 miliona evra) i Evropskog fonda za prilagođavanje globalizaciji (179 miliona evra) tokom 2020. godine. Videti: "Communication from the Commission: Coordinated economic response to the Covid-19 outbreak", Brussels, 13.3.2020, COM(2020) 112, final.

${ }^{2}$ Regulatorni okvir uspostavljen Lisabonskim ugovorom inspirisan je dotadašnjom dobrom praksom i rešenjima prisutnim u Sveobuhvatnom sporazumu o ekonomskoj i trgovinskoj
} 
unije, problematika stranih direktnih investicija prešla je iz državne nadležnosti u isključivu nadležnost Evropske unije, kao dela njene zajedničke trgovinske politike. ${ }^{3}$ Glavni razlog zbog kojeg je došlo do prenosa nadležnosti u oblasti stranih investicija sa država članica na Evropsku uniju jeste nastojanje Unije da ojača svoju poziciju u bilateralnim i multilateralnim pregovorima o trgovinskoj politici, te da time ostvari bolje uslove za domaće investitore u trećim zemljama. U skladu sa prenetim nadležnostima, Evropska unija je stekla pravo na zaključenje novih investicionih ugovora: $U$ praksi je to dovelo do pokretanja bilateralnih pregovora radi postizanja pravičnijih rešenja o slobodnoj trgovini. Primera radi, pregovori su vođeni sa Australijom, Kanadom, Čileom, Indijom, Indonezijom, Japanom, Meksikom, Marokom, Novim Zelandom, Filipinima, Singapurom, Vijetnamom i Turskom, Kinom i Mjanmarom, pa i sa nekim državama članicama regionalnih organizacija poput MERCOSUR-a i ASEAN-a. Evropska unija je delom uspela da ispregovara zaključenje novih bilateralnih sporazuma sa određenim državama, ujedno prihvatajući podeljenu odgovornost u odnosu na sporove koji su proizašli ili koji mogu proizaći iz neizvršavanja ranije zaključenih bilateralnih investicionih aranžmana država članica. U novim bilateralnim sporazumima između Evropske unije i trećih zemalja, Evropska unija je uspela da unapredi zaštitu industrijske svojine i intelektualnih prava svojih preduzeća, kao i obezbeđenje slobodnog priliva stranog investicionog kapitala na svom tržištu i slobodan pristup sopstvenog

saradnji sa Kanadom (The EU-Canada Comprehensive Economic and Trade Agreement - CETA) i u Sporazumu o slobodnoj trgovini sa Singapurom (The EU-Singapore Free Trade Agreement - FTA), iz 2014. godine. Videti: "Towards a Comprehensive European International Investment Policy", European Commission Communication, COM(2010)343 final, 7 July 2010.

3 "Treaty on the Functioning of the European Union, as adopted by the Treaty of Lisbon (TFEU)", 2010, Official Journal C 83/49; "Treaty of Lisbon amending the Treaty on European Union and the Treaty Establishing the European Community", 2007, Official Journal C 306/1; Novi pravni okvir Evropske unije doveo je do prevage evropskog prava nad pravnim režimom uspostavljenim bilateralnim investicionim sporazumima (BITs). Navedeni pristup najpre je prihvaćen od strane Komisije koja se pozvala na član 351, stav 2 Ugovora o funkcionisanju Evropske unije. Tom odredbom obavezuju se države članice da eliminišu nesaglasnosti između prihvaćenih međunarodnih obaveza i prava Unije. Evropski sud pravde takođe je prihvatio ovo stanovište smatrajući da postoji supremacija prava Evropske unije u odnosu na međunarodne pravne obaveze država članica prihvaćene pre njihovog pristupanja Uniji. Videti: Aleksandar Ćirić, Predrag Cvetković, „Karakteristike pravnog režima stranih direktnih investicija u pravu EU“, Zbornik radova Pravnog fakulteta u Nišu, 2014, vol. LIII, br 68, str. 684-686; Radovan Vukadinović, „Štetno dejstvo arbitražnog rešavanja sporova iz internih sporazuma Evropske unije o zaštiti stranih investicija na pravni poredak Evropske unije", Anali Pravnog fakulteta $u$ Beogradu, 2017, vol 65, br. 3, str. 50-69. U pravnoj doktrini smatra se da je Evropska unije preuzela obaveze iz bilateralnih investicionih ugovora država članica po osnovu „funkcionalne sukcesije“. Videti: Rober Schütze, An Introduction to European Law, Cabridge University Press, Cambridge, 2015, pp. 61-63. 
investicionog kapitala na tržištima trećih zemalja. ${ }^{4} \mathrm{Na}$ planu multilateralnog pregovaranja, Evropska unija se pridržavala principa međusobno korisne saradnje sadržanog u Opštem sporazumu o trgovini i uslugama Svetske trgovinske organizacija, u Kodeksu o liberalizaciji kretanja kapitala Organizacije za ekonomsku saradnju i razvoj, kao i u Smernicama za donošenje politika globalnih investicija Grupe G20. ${ }^{5}$ Ovakav pristup doveo je do dalje liberalizacije investicionih tokova sa inostranstvom i do izrade nove investicione politike. Novi pristup stranim investicijama vođen je ciljevima koji opredeljuju delovanje Evropske unije na spoljom planu, a koji obuhvataju primenu opštih demokratskih standarda poput poštovanja ljudskih prava i osnovnih sloboda, potom poštovanja principa održivog razvoja, primenu radnih i ekoloških standarda, principa korporativne odgovornosti, kao i prava zemlje domaćina da reguliše svoj ekonomski sistem u javnom interesu. ${ }^{6}$ Konačno, usvajanjem nove investicione politike i pravnog okvira uspostavljenog Ugovorom iz Lisabona i Ugovorom o funkcionisanju Evropske unije, jasno je da je Evropska unija stekla pravo da samostalno reguliše ovu materiju na načelima ravnopravnosti i nediskriminacije i u skladu sa ciljevima zajedničke trgovinske

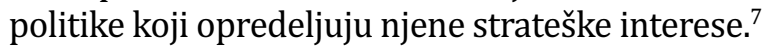

\footnotetext{
${ }^{4}$ Pritom, bilateralni investicioni ugovori između država članica i trećih država koji su zaključeni pre 1. decembra 2009. godine, po odobrenju Komisije, održavani su na snazi do momenta dok nisu bili zamenjeni novim ugovorima između trećih država i Evropske unije, odnosno mogli su biti izmenjeni u skladu sa Uredbom br. 1219/2012 od 12. decembra 2012. godine. Za bilateralne ugovore zaključene između 1. decembra 2009. i 9. januara 2013. godine utvrđeno je pravilo da ostaju na snazi ili stupaju na snagu ako se, prema mišljenju Komisije, ne kose sa drugim propisima Evropske unije. Uredba br. 1219/2012 propisuje posebne uslove za primenu više od 1.400 bilateralnih investicionih ugovora, kao i uslove za njihovo osnaženje i zaključenje novih. Videti: "Regulation (EU) No 1219/2012 of the European Parliament and of the Council of 12 December 2012 establishing transitional arrangements for bilateral investment agreements between Member States and third countries", Official Journal L 351, 20.12.2012, pp. 40-46; List of the bilateral investment agreements referred to in Article 4(1) of Regulation (EU) No 1219/2012 of the European Parliament and of the Council of 12 December 2012 establishing transitional arrangements for bilateral investment agreements between Member States and third countries, Official Journal C 147, 11.5.2017, pp. 1-105.

5 "World Trade Organisation Legal Texts", https://www.wto.org/english/docs_e/legal_e/ legal_e.htm\#services, pristupljeno: 16.02.2021; "The OECD Code of Liberalisation of Capital Movements“, 2018: https://www.oecd.org/daf/inv/investment-policy/Code-CapitalMovements-EN.pdf, pristupljeno: 16.02.2021; "Guiding Principles for Global Investment Policymaking", G20 Trade Ministers Meeting Statement, Annex III, Shanghai, 9-10 July 2016.

${ }^{6}$ Catharine Titi, "International Investment Law and the European Union: Towards a New Generation of International Investment Agreements", EJIL, 2015, vol 26, no. 3, pp. 644-646.
}

${ }^{7}$ August Reinisch, Essentials of EU Law, Cambridge University Press, Cambridge, 2012, p. 247. 


\section{3) ODGOVOR EVROPSKE UNIJE NA PREUZIMANJE EVROPSKIH PREDUZEĆA}

Poslednjih godina Evropska unija težila je da ostane što doslednija na planu liberalizacije investicionog poslovanja. Ovo nastojanje, međutim, bilo je praćeno njenom zabrinutošću zbog sve većeg broja preuzimanja evropskih preduzeća sa tehnologijama u strateški važnim granama evropske privrede. Pomenuti trend bio je konstatovan od strane Komisije još 2017. godine, u „Mišljenju o iskorišćavanju globalizacije“, i u nešto kasnijem Saopštenju: „Moderna trgovinska politika za ostvarivanje globalizacije" sa Izveštajem o sprovođenju trgovinske strategije Evropske unije: „Trgovina za sve“. ${ }^{8}$ Reakcija Komisije usledila je nakon uspostavljanja neprimerenih barijera i nepružanja jednakih uslova za investicije iz Evropske unije na tržištima trećih zemalja, kao i nakon nelojalnog preuzimanja evropskih preduzeća, što je sve zajedno bilo u koliziji sa evropskom zajedničkom trgovinskom i investicionom politikom. ${ }^{9}$ Zaključivanjem niza sporazuma o trgovini i investicijama sa trećim državama, Evropska unija je predvidela niz izuzetaka od pravila nacionalnog tretmana i slobodnog pristupa unutrašnjem tržištu. $\mathrm{S}$ tim u vezi, u Zajedničkom saopštenju: „EU-Kina, strateška perspektiva“ (EU-China - A Strategic Outlook), iz 2019. godine, Evropska unija je identifikovala Kinu ne samo kao ekonomskog partnera i tržišnog takmaca, već i kao sistemskog rivala čije investicije u kritičnu imovinu, tehnologije i infrastrukturu nose sa sobom izvesne bezbednosne rizike. ${ }^{10} \mathrm{U}$ cilju prevazilaženja ovih rizika i Evropska unija je krajem 2020. godine, postigla konstruktivni dogovor oko zaključenja Sveobuhvatnog sporazuma o investicijama sa Kinom (EU-China Comprehensive Agreement on Investment). ${ }^{11}$ Iako konačan tekst Sporazuma nije ratifikovan, činjenica je da se

\footnotetext{
8 "Reflection Paper on Harnessing Globalisation, Europen Commission", COM (2017), 10 May 2017; "Communication from the Commission to the European Parliament, the Council, the European Economic and Social Committee and the Committee of the Regions - A Balanced and Progressive Trade Policy to Harness Globalisation", COM(2017) 492 final, 13. September 2017; "Report From the Commission to the European Parliament, the Council, the European Economic and Social Committee and the Committee of the Regions - Report on the Implementation of the Trade Policy Strategy Trade for All Delivering a Progressive Trade Policy to Harness Globalisation", COM(2017) 491 final, 13 September 2017.

9 "Report from the Commission to the European Parliament and the Council on Trade and Investment Barriers", COM (2017) 338 final, 1 January 2016-31 December 2016.

10 "Joint Communication to the European Parliament, the European Council and the Council: EUChina - A Strategic Outlook", European Commission, Strasbourg, 12.3.2019, JOIN (2019) 5 final.

11 "EU-China Comprehensive Agreement on Investment" European Commission, December 30, Brussels, https://ec.europa.eu/commission/presscorner/detail/en/FS_20_2544, pristupljeno: 15.02.2021.
} 
njime regulišu različita područja investicionog poslovanja koja su ranije bila uređena mnogobrojnim bilateralnim investicionim sporazumima. Zamena ovih aranžmana novim Sveobuhvatnim sporazumom o investicijama, trebalo bi da donese veću pravnu sigurnost, a time i zdravije ekonomsko okruženje neophodno za ispunjenje ciljeva zajedničke trgovinske i investicione politike Evropske unije. Tekst Sporazuma reguliše pitanja slobodnog i ravnopravnijeg pristupa evropskih investicionih preduzeća kineskom tržištu u ključnim ekonomskim oblastima (na primer, u automobilskoj, hemijskoj, mašinskoj, poljoprivrednoj i prehrambenoj industriji, energetici, finansijskom, zdravstvenom i ekološkom sektoru, avio i pomorskom saobraćaju, telekomunikacijama, istraživačkom i razvojnom sektoru itd.). Sporazumom se, nezavisno od kineske unutrašnje politike, garantuje „minimum standarda“ o nacionalnom tretmanu uz istovremeno ustanovljavanje tzv. negativne liste za sve proizvodne i uslužne delatnosti, a što je na liniji rešenja sadržanih u najnovijem kineskom zakonodavstvu o stranim ulaganjima. Sledstveno, predviđena ugovorna rešenja ne ukidaju samo kvantitivna već i kapitalna ograničenja, čime se otvara mogućnost za ostvarenje zajedničkih ulaganja u strateški važnim industrijskim granama. Ovim pristupom izjednačavaju se uslovi i utvrđuju nova pravila za investicije državnih kineskih preduzeća u Evropskoj uniji. Potom, propisuju se obaveze u vezi transparentnosti odobravanja državnih subvencija kineskim privrednim subjektima prisutnim na evropskom tržištu, kao i njihova odgovornost u vezi zabrane prisilnog transfera tehnologija i poštovanja pravila i principa iz Konvencija Međunarodne organizacije rada o zaštiti osnovnih prava zaposlenih, i iz Pariskog sporazuma o klimi. Posebne ugovorne odredbe odnose se na ekološke standarde i održivi ekonomski razvoj. ${ }^{12}$ Iako su dve strane na ovaj način formalno otklonile ranije razmirice u pogledu trgovinske konkurencije i investicionog rivalstva, ipak Sporazumom nisu do kraja otklonile i sve razloge koji opterećuju međusobne ekonomske odnose. Moguće sporne situacije u vezi investicionog i trgovinskog poslovanja trebalo bi, prema Sporazumu, rešavati kroz panele u čijim aktivnostima bi mogli participirati i predstavnici civilnog društva. Potreba za nastavkom konstruktivnog dijaloga dovela je u međuvremenu do unapređenja međusobnih trgovinskih odnosa. 0 tome govore i najnoviji ekonomski podaci koji ukazuju da je Kina nadmašila poziciju Sjedinjenih Američkih Država kao vodećeg trgovinskog parntera Evropske unije. Međutim, u uslovima krize izazvane pandemijom virusa Covid-19, Evropska unija ne isključuje mogućnost

${ }^{12}$ Koncept održivog ekonomskog razvoja prvobitno je ugrađen u Strategiju Evropske unije: Evropa 2020. Videti: "Europe 2020: A strategy for smart, sustainable and inclusive growth", European Commission Communication, Brussels, 3.3.2010, COM(2010)2020. Nakon toga, Evropska unija je donela akcioni plan za ostvarivanje zacrtanih ciljeva održivog razvoja. Videti: "Next steps for a sustainable European futureEuropean - action for sustainability", European Commission Communication, Strasbourg, 22.11.2016, COM(2016) 739 final. 
preduzimanja restriktivnih mera prema kineskim investicionim preduzećima. Doduše, tu mogućnost ne isključuje ni prema svim drugim investitorima iz trećih zemalja iz razloga zaštite sopstvene bezbednosti i javnog poretka. Ovo tim pre, jer u kriznim vremenima države članice moraju iskoristiti sve dostupne instrumente na nivou Unije kako ne bi došlo do gubitka imovine i tehnologija u ključnim industrijskim granama zbog nelojalnog delovanja tzv. predatorskog kapitala. Pravila Evropske unije kojima se štite legitimni ekonomski interesi od priliva takvog kapitala sadržana su u Uredbi Evropskog Parlamenta i Saveta 2019/454 o uspostavljanju okvira za proveru stranih direktnih investicija u Evropskoj uniji. ${ }^{13}$

\section{4) EVROPSKI PRAVNI OKVIR ZA PROVERU STRANIH DIREKTNIH INVESTICIJA}

Uredba 2019/454 o uspostavljanju okvira za proveru stranih direktnih investicija usvojena je 19. marta 2019. godine, a stupila je na snagu 10. aprila 2019. godine. ${ }^{14} \mathrm{Pre}$ njene zvanične primene (do 11. oktobra 2020. godine), u Saopštenju Komisije od 26. marta 2020. godine data su odgovarajuća uputstva i smernice državama članicama o korišćenju postojećih i uspostavljanju novih mehanizama kontrole stranih direktnih investicija u kritičnim sektorima evropske privrede u uslovima širenja pandemije Covid-19. ${ }^{15}$ Početak primene Uredbe 2019/4 označio je efektuiranje evropskog pravnog okvira za proveru stranih direktnih investicija u strateški važnim ekonomskim oblastima poput energetike, finansija, avio i vodnog saobraćaja, komunikacija, zdravstva, tehnologija, usluga, medija itd. ${ }^{16}$ Sa aspekta pravnog dometa, ovaj pravni okvir nadopunjuje druge primarne akte iz različitih sektorskih politika Evropske unije. Generalno uzevši, Uredba reguliše proveru stranih direktnih investicija, s tim što sami mehanizmi kontrole ostaju u ekskluzivnoj nadležnosti država članica. Ovo stoga, što se kontrola vrši iz razloga zaštite javnog poretka i nacionalne bezbednosti. Primena mehanizama kontrole ne isključuje u potpunosti mogućnost narušavanja slobodne

13 "Regulation (EU) 2019/452 of the European Parliament and of the Council of 19 March 2019 establishing a framework for the screening of foreign direct investments into the Union", Official Journal L 79, 21 March, 2019.

${ }^{14}$ Duško Dimitrijević, „Uredba Evropskog parlamenta i Saveta o uspostavljanju okvira za proveru stranih direktnih investicija u Evropskoj uniji", Evropsko zakonodavstvo, 2019, vol. XVIII, br. 68, str. 7-25.

15 "Communication from the Commission: Guidance to the Member States concerning foreign direct investment and free movement of capital from third countries, and the protection of Europe's strategic assets, ahead of the application of Regulation (EU) 2019/452 (FDI Screening Regulation)", Official Journal C 99 I/1, 26.03.2020.

${ }^{16} \mathrm{U}$ odnosu na portfeljna strana ulaganja, koja ne predstavljaju problem u smislu bezbednosti i javnog poretka, provera se vršu u skladu sa ugovorom o slobodnom kretanju kapitala. 
trgovine, odnosno slobodnog protoka kapitala u odnosima sa trećim zemljama. To, naravno, ne znači da bi svaka država za sebe mogla uvoditi neopravdane i diskriminatorske mere prema stranim investitorima isključivo s pozivom na zaštitu sopstvenog javnog poretka i bezbednosti, već naprotiv, države u svakom slučaju moraju voditi računa da njihovi mehanizmi kontrole stranih investicija budu usklađeni sa opštim interesima Evropske unije. ${ }^{17}$ Ovi interesi anticipiraju primenu principa nužnosti, proporcionalnosti i pravne sigurnosti koji predstavljaju branu mogućoj diskriminaciji, netransparentnosti i zloupotrebama. ${ }^{18}$ Smatra se, naime, da je jedino na ovaj način moguće afirmisati ravnopravnije uslove investicionog poslovanja i pravne zaštite u skladu sa ciljevima zajedničke trgovinske i investicione politike za koju je Evropska unija isključivo nadležna. ${ }^{19}$ Pomenuti pristup omogućava efikasnije povezivanje evropske privrede u globalni lanac vrednosti, što je jedan od prioriteta Evropskog investicionog plana, Agende održivog razvoja 2030, i drugih evropskih i međunarodnih programa i projekata. ${ }^{20}$ Sledstveno ustanovljenom pravnom okviru, države članice Evropske unije dužne su da uspostavljaju međusobnu saradnju, i

${ }^{17}$ Stav Evropskog suda pravde po ovom pitanju je u potpunosti jasan budući da Evropski sud tvrdi da: „iako države članice imaju diskreciono pravo u pogledu određivanja razloga javnog poretka i bezbednosti u kontekstu nacionalnih potreba, ove interese države članice ne mogu utvrđivati jednostrano bez ikakve kontrole institucija Evropske unije“. U tom smislu, javni interesi se moraju striktno tumačiti tako da, „interesi postoje isključivo ako postoji stvarna i dovoljno ozbiljna pretnja opštem interesu društva“. Videti: Case C-483/99, Commission v France, Case C-463/00, Commission v Spain, Case C-326/07, Commission v Italy, Case C-212/09 Commission v Portugal, and Case C-244/11 Commission v Greece. U slučaju Commission v Italy, Case C-531/06, Evropski sud pravde prepoznao je javno zdravlje kao „preovladavajući razlog u opštem interesu“.

${ }^{18}$ Prilikom izrade predloga Uredbe, Komisija se oslonila na Smernice za politike ulaganja u države primaoce u pogledu nacionalne bezbednosti i Kodeks o liberalizaciji kretanja kapitala Organizacije za ekonomsku saradnju i razvoj. Videti: "Proposal for a Regulation of the European Parliament and of the Council establishing a framework for screening of foreign direct investments into the European Union", COM(2017) 487 final, 13 September 2017; "Guidelines for Recipient Country Investment Policies Relating to National Security", Recommendation adopted by the OECD Council on 25 May 2009, http://www.oecd.org/daf/inv/investmentpolicy/43384486.pdf, pristupljeno: 16.02.2021; "The OECD Code of Liberalisation of Capital Movements", 2018, https://www.oecd.org/daf/inv/investment-policy/Code-CapitalMovements-EN.pdf, pristupljeno: 16.02.2021.

19 "Trade for All: Towards a more responsible trade and investment policy", Communication, COM (2015) 497, 14 October 2015.

20 “What is the Investment Plan for Europe?", European Commission, Internet: https://ec.europa. eu/commission/priorities/jobs-growth-and-investment/investment-plan-europe-junckerplan/what-investment-plan-europe_en, pristupljeno: 20.01.2021; "Transforming our World: the 2030 Agenda for Sustainable Development", United Nations, A/RES/70/1; Duško Dimitrijević, „Saopštenje Komisije o prihvatanju stranih direktnih investicija uz zaštitu vitalnih interesa", Evropsko zakonodastvo, 2018, br. 65, str. 71-84. 
saradnju sa trećim državama, i da usklađuju svoje odnose sa Komisijom u svrhu očuvanja javnog poretka i bezbednosti. ${ }^{21}$ Već uspostavljeni sistemi kontrole stranih direktnih investicija na nacionalnim nivoima, ostaju prema pravnom okviru i dalje na snazi. Države članice preuzele su obavezu da do 10. maja 2019. godine informišu Komisiju o postojanju tih mehanizama, kao i o potrebi njihove zamene, odnosno uspostavljanja novog i sveobuhvatnijeg sistema kontrole. Sa druge strane, Komisija je prihvatila obavezu da sastavi spisak postojećih kontrolnih mehanizama u roku od tri meseca. Konačno, Komisija je zadužena da podstiče saradnju na proveri stranih investicija, uključujući razmenu iskustava, najboljih praksi i informacija o pitanjima od zajedničkog interesa. Ona može postaviti određene zahteve državama članicama koje žele da zadrže ili usvoje mehanizam provere na nacionalnom nivou. Prema pravnom okviru sva pravila postupka provere morala bi biti transparentna, te se investitorima mora garantovati pravna zaštita s obzirom na odluke donete u postupcima kontrole. Kontrola stranih direktnih investicija ne zavisi isključivo od vrednosti same investicione transakcije, već od procene rizika za bezbednost i javni poredak država članica. Stoga, kontrola podrazumeva obavezu država članica da vrše proveru svih onih stranih ulaganja koja mogu imati negativne posledice na kritičnu infrastrukturu, tehnologije, robu sa dvojnom namenom, snabdevanja ključnim resursima, na medije i delatnosti koje se odnose na pristup osetljivim informacijama itd. ${ }^{22}$ Prilikom kontrole države moraju obratiti pažnju i na vlasničku strukturu investitora i njegovu povezanost sa stranom državom. Pravni okvir posvećuje posebnu pažnju godišnjim izveštajima država članica u kojima se vrši investiranje i procedurama izdavanja mišljenja Komisije $\mathrm{u}$ vezi postojanja rizičnih investicija. ${ }^{23} \mathrm{U}$ drugom pomenutom slučaju, Komisija poseduje specifična ovlašćenja u odnosu na projekte ili programe od posebnog interesa

${ }^{21}$ Pomenuti razlozi bliže su propisani Sporazumom Međunarodne trovinske organizacije, posebno odredbom iz člana 14 Sporazuma o slobodnoj trgovini i carinama, kao i drugim odredbama iz međunarodnih pravnih instrumenata o trgovini i investicijama čije strane ugovornice su države članice ili Evropska unija.

22 "Regulation (EU) 2016/679 of the European Parliament and of the Council of 27 April 2016 on the protection of natural persons with regard to the processing of personal data and on the free movement of such data, and repealing Directive 95/46/EC" (General Data Protection Regulation), Official Journal L 119, 4.5.2016; "Regulation (EU) 2018/1725 of the European Parliament and of the Council of 23 October 2018 on the protection of natural persons with regard to the processing of personal data by the Union institutions, bodies, offices and agencies and on the free movement of such data, and repealing Regulation (EC) No 45/2001 and Decision No 1247/2002/EC", Official Journal L 295, 21.11.2018.

${ }^{23}$ Komisija izdaje mišljenje nakon dostavljanja primedbi drugih država ili prikupljanja dodatnih informacija, a najkasnije u roku od 20 dana. U takvim slučajevima smatra se da mišljenje valja izdati u razumnom roku (najkasnije u roku od 35 dana nakon prijema informacija). U svakom pojedinačnom slučaju, Komisija izdaje mišljenje tek kada utvrdi da je jedna trećina obuhvaćenih država našla da konkretna investicija (koja podleže i koja ne podleže kontroli) 
za Evropsku uniju. ${ }^{24}$ Ovlašćenja se odnose na kontrolu projekata i programa koji su taksativno nabrojani u Uredbi, i to: Horizont 2020, Galileo, Evropski geostacionarni navigacijski sistem (EGNOS), Kopernikus, transevropske mreže u sektorima prometa (TEN-T), energetike (TEN-E) i telekomunikacija (eTEN) i Evropski program industrijskog razvoja u oblasti odbrane i stalne strukturne saradnje (PESCO). Navedeni projekti i programi povlače znatna finansijska sredstva zbog čega se pridaje veliki značaj njihovoj realizaciji. Razlozi javnog poretka ili bezbednosti principijelno se i ne dovode u pitanje u njihovom slučaju. Ovo tim pre, jer su programi i projekti uspostavljeni na osnovu zakonodavstva Evropske unije u strateški važnim ekonomskim oblastima za koje Komisija ima delegirana ovlašćenja. Uzimajući u obzir sve relevantne činjenice, Komisija nakon provere (koja uključuje i vođenje poverljivih konsultacija sa specijalnim stručnim timovima), iznosi svoja mišljenja u cilju procene bezbednosnih rizika. Komisijska mišljenja, iako nisu pravno obavezujuća za države članice, ipak uživaju određeni autoritet koji proizilazi iz principa lojalne saradnje. ${ }^{25}$ Valja istaći još i da rezultati provere ne moraju nužno biti iskazani kroz zabranu stranih investicija, već mogu uključivati primenu odgovarajućih mera kojima se ublažava rizik za nacionalnu bezbednost i javni poredak, tj. za celokupnu evropsku ekonomiju (npr. zadržavanjem posebnih prava ili tzv. zlatnih akcija u strateški važnim preduzećima).

\section{5) SEKTORSKA PRIMENA OKVIRA ZA PROVERU STRANIH INVESTICIJA}

Evropski pravni okvir za proveru stranih direktnih investicija ima suplementarno dejstvo u odnosu na propise u drugim sektorskim politikama Evropske unije. Tako se za oblast koncentracije kapitala koja se odvija kroz spajanja, pripajanja ili zajednička ulaganja preduzeća, provera reguliše najpre na osnovu Uredbe o koncentraciji kapitalnih ulaganja. ${ }^{26}$ Prema njenim odredbama, strani

može uticati na njihov javni poredak ili nacionalnu bezbednost. Za investicije koje ne podležu kontroli, Komisija može izdati mišljenje i u roku od 15 meseci nakon što je investiciono ulaganje sprovedeno. Uredba u tom smislu ne predviđa retroaktivno važenje za investicije sprovedene pre 10. aprila 2019. godine.

24 "Regulatory Fitness and Performance Programme - REFIT Scoreboard Summary", European Commission, 24 October 2017.

${ }^{25}$ Država članica na čijem se području sprovodi, ili se planira sprovođenje strane direktne investicije, ima obavezu da razmotri i usvoji navedeno mišljenje, odnosno ima pravo da odbije mišljenje Komisije, i u tom slučaju je obavezna da pruži razložno obrazloženje. Međutim, država na čijem području se sprovodi, ili se planira sprovođenje strane direktne investicije, ima obavezu da obavesti Komisiju i druge zainteresovane države.

26 "Council Regulation (EC) No 139/2004 of 20 January 2004 on the Control of Concentrations between Undertakings", Official Journal L, 24, 29.1.2004, pp. 1, etc. 
investitori imaju dužnost da poštuju pravila o tržišnom poslovanju koja uključuju kontrolu spajanja i pripajanja preduzeća. Principijelno, strane investicije se neće realizovati sve dok Komisija ne izvrši proveru. Cilj ove provere jeste sprečavanje kapitalnih koncentracija koje bi mogle znatno otežati tržišnu kompeticiju, i time dovesti u pitanje bezbednost ili javni poredak država članica. Države članice otud imaju ovlašćenja da preduzimaju zaštitne mere. Ako bi u praksi došlo do preklapanja primene odredaba iz ove Uredbe i evropskog pravnog okvira za proveru stranih direktnih investicija, ne bi se dovodila u pitanje procena usklađenosti zaštitnih mera preduzetih na državnom nivou sa opštim načelima i drugim obavezama koje proizilaze iz prava Evropske unije. Za finansijsku oblast, provera se vrši na osnovu Direktive 2007/44/EZ o pravilima postupanja i kriterijumima procene za bonitetnu procenu sticanja i povećanja udela u finansijskom sektoru, Direktive 2013/36/EU o pristupanju delatnosti kreditnih ustanova i bonitetnoj kontroli na kreditnim ustanovama i investicionim fondovima, Direktive 2009/138/EZ o osnivanju i obavljanju delatnosti osiguranja i reosiguranja (Solventnost II) i Direktive 2014/65/EU o tržištu kapitala. ${ }^{27}$ Načelno, evropski pravni okvir za proveru stranih direktnih investicija ne može uticati na propisane kriterijume Evropske unije u vezi bonitetnog nadzora vezanog za sticanje kvalifikovanog udela u finansijskom sektoru. Za oblast energetike, postupak provere ustanovljen je Direktivom o kritičnoj infrastrukturi kojom se od država članica zahteva da utvrde strateški važnu infrastrukturu za koju države imaju obavezu da pripreme adekvatne bezbednosne planove. ${ }^{28}$ Zajedno sa direktivama obuhvaćenim tzv. Trećim energetskim paketom, Evropska unija je propisala pravila kojima se regulišu posledice koje mogu nastati po države članice i Uniju u celini, kada sistem prenosa gasa i električne energije

\footnotetext{
27 "Directive 2007/44/EC of the European Parliament and of the Council of 5 September 2007 amending Council Directive 92/49/EEC and Directives 2002/83/EC, 2004/39/EC, 2005/68/EC and 2006/48/EC as regards procedural rules and evaluation criteria for the prudential assessment of acquisitions and increase of holdings in the financial sector", Official Journal L, 21.9.2007, pp. 1-16; "Directive 2013/36/EU of the European Parliament and of the Council of 26 June 2013 on access to the activity of credit institutions and the prudential supervision of credit institutions and investment firms, amending Directive 2002/87/EC and repealing Directives 2006/48/EC and 2006/49/EC", Official Journal L, 176, 27.6.2013, pp. 338-436; "Directive 2009/138/EC of the European Parliament and of the Council of 25 November 2009 on the taking-up and pursuit of the business of Insurance and Reinsurance (Solvency II)", Official Journal L, 335, 17.12.2009, pp. 1-155; "Directive 2014/65/EU of the European Parliament and of the Council of 15 May 2014 on markets in financial instruments and amending Directive 2002/92/EC and Directive 2011/61/EU", Official Journal L, 173, 12.6.2014, pp. 349-496.

28 "Council Directive 2008/114/EC of 8 December 2008 on the Identification and Designation of European critical Infrastructures and the Assessment of the Need to Improve their Protection", Official Journal L, 345, 23.12.2008, p. 75.
} 
kontroliše operater iz države van Evropske unije. ${ }^{29}$ Evropska unija je propisala i odgovarajuće obaveze za države članice u pogledu procene rizika na državnom i regionalnom nivou, a radi sveukupne bezbednosne procene $u$ vezi sa sistemima za snabdevanje gasom, uključujući rizike koji su povezani sa gasnom infrastrukurom. ${ }^{30}$ Uz navedeno, u predlogu Uredbe o pripremljenosti za rizike, sadržane su „manjeviše" istovetne odredbe za oblast snabdevanja električnom energijom. ${ }^{31}$ U Direktivi o bezbednosti mrežne infrastrukture, takođe su navedeni subjekti odgovorni za pružanje energetskih usluga. ${ }^{32} \mathrm{U}$ Strategiji za evropsku energetsku bezbednost iz 2014. godine, analizirana je situacija kad privredni subjekti izvan Evropske unije preuzmu kontrolu nad strateški važnim infrastrukturim objektima u energetskoj oblasti. ${ }^{33} \mathrm{U}$ tom smislu, posebna pažnja Komisije usmerena je na kompanije, banke i investicione fondove u državnom vlasništvu iz zemalja glavnih snabdevača energentima, čiji je cilj da uđu na tržište Evropske unije i da stvore prepreke diversifikaciji energetskog snabdevanja i razvoja mreže i infrastrukture u Uniji. Komisija smatra da bi kroz davanje zakonodavnih predloga u vezi sa obezbeđenjem snabdevanja električnom energijom i gasom države članice trebalo da preduzmu i odgovarajuće mere kojim bi procenile rizike preuzimanja vlasničke ili upravljačke kontrole nad energetskim infrastrukturnim objektima od strane pravnih subjekata iz trećih zemalja. Usvojene mere bi prema stanovištu Komisije, morale biti ispitane od strane stručnih tela u svakom pojedinačnom slučaju. Za oblast trgovine, koja ima stratešku važnost za lanac snabdevanja evropske privrede, Komisija od 2008. godine svake tri godine ažurira spisak kritičnih dobara nužnih za razvoj tržišta i obavljanje redovnih privrednih delatnosti. ${ }^{34} \mathrm{Za}$ oblast izvoza robe sa dvojnom namenom

29 "Directive 2009/72/EC of the European Parliament and of the Council of 13 July 2009 concerning Common Rules for the Internal Market in Electricity and Repealing Directive 2003/54/EC", Official Journal L, 211, 14.8.2009, p.55; “Directive 2009/73/EC of the European Parliament and of the Council of 13 July 2009 concerning Common Rules for the Internal Market in Natural Gas and Repealing Directive 2003/55/EC", Official Journal L, 211, 14.8.2009, pp. 94, etc.

30 "Regulation (EU) No 994/2010 of the European Parliament and of the Council of 20 October 2010 concerning Measures to Safeguard Security of Gas Supply and Repealing Council Directive 2004/67/EC Text with EEA relevance”, Official Journal L, 295, 12.11.2010, pp. 102, etc.

31 "Proposal for a Regulation of the European Parliament and of the Council on Risk-Preparedness in the Electricity sector and repealing Directive 2005/89/EC", COM (2016) 862.

32 "Directive (EU) 2016/1148 of the European Parliament and of the Council of 6 July 2016 concerning measures for a high common level of security of network and information systems across the Union", Official Journal L, 194, 19.7.2016, pp. 1, etc.

33 "Communication from the Commission to the European Parliament and the Council, European Energy Security Strategy", COM, 2014.

34 "Communication: Tackling the Challenges in Commodity Markets and on Raw Materials", COM(2011)25. 
evropski pravni okvir ne uspostavlja kontrolne mehanizme, zbog čega se njena regulacija prepušta tumačenju odredaba iz Uredbe 428/2009, koje upućuju na poštovanje međunarodno preuzetih obaveza i obezbeđenje međunarodne bezbednosti. ${ }^{35} \mathrm{Za}$ oblast vazdušnog saobraćaja, provera se vrši u skladu sa Uredbom $1008 / 2008$ koja propisuje uslove za izdavanje operativnih licenci za obavljanje vazdušnog saobraćaja. Pretpostavlja se da je većina vlasnika u ovoj delatnosti u državnom vlasništvu ili u vlasništvu državljana država članica Evropske unije. Obaveza nadzora stranih direktnih investicija ovom Uredbom pripisana je upravo vlasnicima, te stoga, za strane investitore važi pravilo da ne bi mogli dobiti dozvolu u Evropskoj uniji za avio prevoz ako bi izvan Unije posedovali većinski udeo u kapitalu, osim ako postoji bilateralni sporazum sa njihovom matičnom zemljom. ${ }^{36}$ Za kontrolu stranih direktnih investicija u tehnološkim oblastima, koje mogu imati strateški značaj za odbranu i bezbednost (npr. umetna inteligencija, robotika, kibernetika, nuklearna tehnologija, kvantna i nanotehnologija, svemirska i biotehnologija), Evropska unija je usvojila posebnu regulativu. ${ }^{37}$ Evropski pravni okvir za proveru stranih direktnih investicija ima samo suplementarno dejstvo u tom pogledu, budući da dopunjava postojeću regulativu, što je možda najuočljivije u oblasti kibernetike gde je donet niz propisa kojima se uspostavlja strategija otvorenog, bezbednog i sigurnog sajber prostora. ${ }^{38}$

35 "Council Regulation (EC) No 428/2009 of 5 May 2009 setting up a Community Regime for the Control of Exports, Transfer, Brokering and Transit of Dual-Use Items", Official Journal L, 134, 29.5.2009, pp.1, etc.

36 "Regulation (EC) No 1008/2008 on Common Rules for the Operation of Air Services in the Community", Official Journal L, 293/3, 31.10.2008.

${ }^{37}$ Na primer: "Communication from the Commission to the European Parliament, the Council, the European Economic and Social Committee and the Committee of the Regions Space Strategy for Europe", COM/2016/0705 final, 26.10.2016.

38 "Regulation (EU) No 283/2014 of the European Parliament and of the Council of 11 March 2014 on Guidelines for trans-European Networks in the Area of Telecommunications Infrastructure and Repealing Decision No 1336/97/EC", Official Journal L, 86, 21.3.2014, pp. 14; "Directive (EU) 2016/1148 of the European Parliament and of the Council of 6 July 2016 concerning Measures for a High Common Level of Security of Network and Information Systems across the Union", Official Journal L, 94, 19.7.2016, pp. 1-30; “Commission Communication COM(2016) 410 on Strengthening Europe's Cyber Resilience System and Fostering a Competitive and Innovative Cybersecurity Industry", $\operatorname{COM(2016)~} 410$ final, 5.7.2016; "Regulation (EU) No 283/2014 of the European Parliament and of the Council of 11 March 2014 on Guidelines for trans-European Networks in the Area of Telecommunications Infrastructure and Repealing Decision No 1336/97/EC", Official Journal L, 86, 21.3.2014. 


\section{6) ZNAČAJ ZA REPUBLIKU SRBIJU}

Usvajanjem pravnog okvira, sadržanog u Uredbi 2019/454, države članice Evropske unije obavezale su se da onemoguće nelojalna preuzimanja strateški važne imovine i tehnologija u ključnim oblastima evropske privrede. Ovu obavezu države sprovode kroz mehanizme kontrole stranih direktnih investicija. S obzirom na to da kontrola investicija povlači odgovarajuća odstupanja od uobičajene trgovinske prakse, njeno sprovođenje mora biti izbalansirano između nediskriminatorskog i predvidljivog poslovnog okruženja i fleksibilnog i transparentno uspostavljenog sistema kontrole. Kao država koja pledira da postane članica Evropske unije, Srbija takođe može prihvatiti neka rešenja sadržana u navedenom pravnom okrivu Evropske unije. Mere koje bi Srbija mogla eventualno preduzeti prema „predatorskom kapitalu”, u vremenu krize izazvane pandemijom virusa Covid-19, mogu se odnositi na odlaganje realizacije zaključenih investicionih aranžmana. Ovo odlaganje bi moglo biti pravdano i razlozima bezbednosti i zaštite javnog poretka. Iz istih razloga, Srbija bi mogla tržiti izmenu ugovorenih uslova vezanih za tzv. kišobran klauzule, kojima se generalno obavezala prema stranim investitorima u strateški važnim granama privrede. Vanredna zdravstvena situacija bi mogla biti dobar ,izgovor" i za odbijanje zahteva za neka buduća nelojalna strana ulaganja. Srbija bi na bazi nužnosti i proporcionalnosti, takođe, mogla preduzeti i određene restriktivne mere u okviru svoje trgovinske politike sa inostranstvom. Ovim merama umanjila bi se mogućnost nastanka investicionog spora. Takođe, da bi se eventualni investicioni sporovi izbegli bilo bi nužno uskladiti domaće zakonodavstvo o investicionom poslovanju sa pravnim standardima prisutnim u uporednom pravu i pravu Evropske unije. Pravna nadogradnja nacionalnog zakonodavstva u tom pogledu morala bi se kretati između obezbeđenja najvišeg stepena pravne sigurnosti za strane investitore i uspostavljanja čvrstih pravnih barijera za sve moguće vrste investicionih zloupotreba.

\section{7) LITERATURA}

Ćirić, Aleksandar, Cvetković, Predrag, „Karakteristike pravnog režima stranih direktnih investicija u pravu EU“, Zbornik radova Pravnog fakulteta u Nišu, 2014, vol. LIII, br 68.

Dimitrijević, Duško, „Saopštenje Komisije o prihvatanju stranih direktnih investicija uz zaštitu vitalnih interesa", Evropsko zakonodastvo, 2018, br. 65.

Dimitrijević, Duško, „Uredba Evropskog parlamenta i Saveta o uspostavljanju okvira za proveru stranih direktnih investicija u Evropskoj uniji“, Evropsko zakonodavstvo, 2019, br. 68.

Reinisch, August, Essentials of EU Law, Cambridge University Press, Cambridge, 2012. 
Schütze, Rober, An Introduction to European Law, Cabridge University Press, Cambridge, 2015.

Titi, Catharine, "International Investment Law and the European Union: Towards a New Generation of International Investment Agreements", EJIL, 2015, vol 26, no. 3.

Vukadinović, Radovan, „Štetno dejstvo arbitražnog rešavanja sporova iz internih sporazuma Evropske unije o zaštiti stranih investicija na pravni poredak Evropske unije“, Anali Pravnog fakulteta u Beogradu, 2017, vol 65, br. 3.

\section{IMPLEMENTATION OF THE EUROPEAN UNION LEGAL FRAMEWORK FOR THE SCREENING OF FOREIGN DIRECT INVESTMENTS DURING THE COVID-19 PANDEMIC}

Summary: The European Union's common trade policy pays special attention to foreign direct investment. This is because foreign direct investment is an important source of economic growth, employment and innovation and a key factor in the Union's socio-economic development. In the period before the outbreak of the Covid-19 virus pandemic, the European Union was the main investor and the most important destination for foreign investment in the world. The spread of the virus has led to disruptions in global supply chains, destabilisation of financial markets, and then to the negative effects of foreign direct investment resulting from the takeover of assets and technologies in strategically important sectors of the European economy. To avoid a new recession, the European Union has reacted decisively in order to protect its own economic interests. Thus, in March 2019, the European Union adopted Regulation 2019/454, which established a legal framework for screening foreign direct investments from third countries. The operational implementation of this legal framework began on 11 October 2020. The member states of the European Union are authorised to supervise foreign direct investments through the existing and newly established screening mechanisms, calling for reasons of security and protection of public order. Screening mechanisms presuppose compliance of domestic legislation with the adopted legal framework. Its implementation in practice should not lead to more drastic deviations from the usual standards of international business in the field of trade and investment.

Key words: European Union, foreign direct investments, control mechanisms, security, public order. 